\title{
III.
}

\section{NOTES ON THE ACTINI尼 OCCURRING IN THE NEIGHBOURHOOD OF THE BIOLOGICAL STATION, ST. ANDREWS, N.B.}

\author{
By Professor J. Playfair MoMurrich, M.A., Ph. D., Professor of Anatomy in the \\ University of Toronto.
}

The only statement regarding the Actinian fauna of Passamaquoddy bay at present on record is the mention by Ganong ${ }^{1}$ of Metridium marginatum as occurring at Craig's ledges. As far back, however, as 1853, Wm. Stimpson ${ }^{2}$ published a list of Actinians obtained at Grand Manan, in which he records six species, identifying them as Actinia marginata Lesueur, A. carneola n. sp., A. obtruncata n. sp., A. coriacea Johnston (?) and A. sipunculoides n. sp. The descriptions that are given of these various forms are unfortunately lacking in precision, according to our modern standards, and it becomes of interest to know their definite positions in our presentday classification. ${ }^{3}$

During a visit to the Biological Station at St. Andrews in 1908, I paid some attention to the Actinian fauna of the neighbourhood with the object of determining the synonomy of Stimpson's forms, and succeeded in obtaining examples of four species, which correspond with five of those described by Stimpson. His sixth species, A. sipunculoides, which is referable either to the genus Edwardsia or to an allied genus, has not yet been taken at the Station.

The most abundant species in the neighbourhood, as well as along the entire New England coast, is Metridium dianthus (Ellis) Oken, which appears in Stimpson's list under the names Actinia marginata Lesueur and Act. dianthus (?) Johnston. The former term was that applied to the American representatives of the species by Lesueur1, under the supposition that they were distinct from the European forms, but several writers have expressed doubts as to their distinctness and an anatomical study of the American forms convinced $\mathrm{me}^{2}$ that they cannot be regarded as distinct. Indeed, the species is to be regarded as circumpolar in its distribution, since it also occurs on our west coast as the forms originally described as $M$. fimbriatum Verrill.

A study of the synonymy of the species shows that it is without doubt identical with the form described by Linnaeus as Actinia senitis, and consequently its proper designation is Metridium senile (Linn.)

1 W. F. Ganong.-The Invertebrata of Passamaquoddy Bay. Bull. Nat. Hist. Soc. New Brunswick, No. IV. 1885.

a Wm. Stimpson.-Synopsis of the Marine Invertebrata of Grand Manan. Smithsonian Contributions to Knowledge, VI. 1853.

3 It should be stated that Verrill has in various papers identified Stimpson's species in essentially the same war as I give them in the following pages, but it seemed well, in the inferest of a definite and readily accessible rec ond of the fauna of the waters in the vicinity of the station, that the identifications should be brought together here in a concise form.

1 C. A. Lesueur.-Observations on several species of Actinia. Journ. Acad. Nat. Sci., Philadelphia, I. 1817.

J.P.McMurrich.-Report on the Hexactiniae of the Columbia University Expedition to Puget Sound during the summer of 1896. An nals N.Y. Acad. Sci. XIV, 1901. 
So far as my limited observations go, only young individuals occur between tidemarks in the neighbourhood of the station, the larger examples being probably confined to deeper water.

A second form, which must also be regarded as circumpolar in its distribution, is Urticina crassicornis (Mull.) Ehr., which I found on the rocks between tide-marks and which has also been dredged in the deeper water of the bay. It is undoubtedly the form which Stimpson described as Actinia obtruncata, and American examples of the species have also been described under the name Rhodactinia davisii $\mathrm{Ag}$. In this case again, a study of the synonymy leads back to a Linnean species Actinia felina, and the correct name is therefore Urticina felina (Linn.) In all the five examples of this species that I collected, the column was of a bright scarlet or claret colour, the colour in the largest individual (height of column $3 \mathrm{~cm}$., diameter $7 \mathrm{~cm}$.) being closely set flakes on a yellowish ground, while in the others it was practically solid. In the largest example the tentacles, which are stout, obtusely pointed and longitudinally ribbed in contraction, were of a solid pink colour except at the base where they were surrounded by a crimson band, from which a prolongation extended upon the disk towards the mouth. In other individuals additional bands were more or less distinctly to be seen surrounding the tentacles.

The species, however, seems to show considerable variation in colouration, that of the column having been described in some cases as solid flesh-colour, while in others the ground colour is green upon which are blotches of scarlet. The species belongs to the family Cribrinidoe and possesses a strong circumscribed, pedunculate, endodermal sphincter muscle.

The third species also belongs to the family Cribrinidae and is the form doubtfully assigned by Stimpson to Johnston's $A$. coriacea. It is not, however, identical with that species but is that which was later described by Verrill ${ }^{1}$ as Bunodes stella. Its proper name is Cribrina stella. I found it at St. Andrews in the crevices of the rocks between tide-marks, and it is readily recogitizable by its brownish or olive green colour and by the rows of verrucæ upon the upper portion of the column, to which particles of gravel and shells adhere. The sphincter is of the circumscribed pedunculate endodermal type.

The fourth species, Stomphia carneola (Stimpson) Verrill, may readily be mistaken for $U$. crassicornis on account of the similarity in the colouration. As in that species the column is of a pale yellowish colour, abundantly flecked or mottled with red so that the general effect is reddish. Towards the margin, however, the reddish colour is much less pronounced than lower down. The tentacles are translucent, but are marked by two circular bands of orange red, the tips being of the same colour, and at the base of each there are one or two opaque white spots. The disk is pale orange red without any markings, except that the peristome is a rich shade of the same colour. The species may be distinguished from $U$. crassicornis by its smaller size, by its tentacles being much more slender and not longitudinally furrowed and by the white spots at the bases of the tentacles whose occurrence has been noted in all individuals described from this side of the Atlantic. Inasmuch as the species belongs to the family Paractidæ an examination of the sphincter, which is of the mesogloeal type, will at once remove all doubt.

Stimpson described his A. carneola in 1853. Six years later Gosse ${ }^{\mathrm{i}}$ described a form from the British coast under the name Stomphia Churchio, and in 1893 Carlgren published an account of its anatomical features as determined from a ${ }^{1}$ A. E. Verrill.-Revision of the Polypi of the eastern coast of the United States. Memoirs
Boston Soc. Nat. Hist. I. 1864.

1 P. H. Gosse.-Charactens and descriptions of some new British Sea-Anemones. Ann. and Mag. Nat. Hist. 3rd Ser. III. 1859.

2 O. Carlgren.-Studien wber uordische Actinien. K. Svenka Vetens. Akad. Handl. XXV. 1893. 
specimen taken upon the coast of Sweden. A comparison of our American form with Carlgren's description led Verrill ${ }^{3}$ to the conclusion that Gosse's Stomphia Churchice was identical with Stimpson's $A$. carneola, a conclusion which I can confirm after a detailed anatomical study of examples of carneola collected at St. Andrews and also of one obtained from Eastport, Me., in all of which I find agreement, even in the details, with the example of Churchice studied by Carlgren. Carlgren has, however, carried the identification a step further, giving reasons for believing that Gosse's $S$. Churchioe is indentical with Müller's Actinia coccinea, in which case the correct name for the species becomes Stomphia coccinea (Müll.) Carlgr.

The four species known to occur in the neighbourhood of the St. Andrews Station are then Metridium senite (Linn.), Urticina felina (Linn.), Cribrina stella (Verr.) and Stomphia coccinea (Müll.) Carlgr.

${ }^{3}$ A. E. Verrill.-Descriptions of imperfectly known and new Actinians with critical notes on other species, IV. Amer. Journ. Sei. 'VII. 1899. 